Publications (in English and Arabic): Annual Report; The Articles of Agreement of the Arab Monetary Fund; Money and Credit in Arab Countries (annual); National Accounts of Arab Countries (annual); Foreign Trade of Arab Countries (annual); Cross Exchange Rates of Arab Currencies (annual); Arab Countries: Economic Indicators (annual); Balance of Payments and External Public Debt of Arab Countries (annual); AMF Publications Catalogue (annual). (In Arabic only): The Joint Arabic Economic Report (annual); AMF Economic Bulletin; Developments in Arab Capital Markets (quarterly).

\section{Arab Organization for Agricultural Development (AOAD)}

The AOAD was established in 1970 and commenced operations in 1972. Its aims are to develop natural and human resources in the agricultural sector and improve the means and methods of exploiting these resources on scientific bases; to increase agricultural productive efficiency and achieve agricultural integration between the Arab States and countries; to increase agricultural production with a view to achieving a higher degree of self-sufficiency; to facilitate the exchange of agricultural products between the Arab States and countries; to enhance the establishment of agricultural ventures and industries; and to increase the standards of living of the labour force engaged in the agricultural sector.

Organization. The structure comprises a General Assembly consisting of ministers of agriculture of the member states, an Executive Council, a Secretariat General, seven technical departments-Food Security, Human Resources Development, Water Resources, Studies and Research, Projects Execution, Technical Scientific Co-operation, and Financial Administrative Department-and two centres-the Arab Center for Agricultural Information and Documentation, and the Arab Bureau for Consultation and Implementation of Agricultural Projects.

Members. Algeria, Bahrain, Comoros, Djibouti, Egypt, Iraq, Jordan, Kuwait, Lebanon, Libya, Mauritania, Morocco, Oman, Palestine, Qatar, Saudi Arabia, Somalia, Sudan, Syria, Tunisia, United Arab Emirates, Republic of Yemen.

Official languages: Arabic (English and French used in translated documents and correspondence).

Headquarters: Street No. 7, Al-Amarat, Khartoum, Sudan. Website: http://www.aoad.org

Director General: Dr Tariq Moosa Al-Zadjali.

\section{Gulf Co-operation Council (GCC)}

Origin. Also referred to as the Co-operation Council for the Arab States of the Gulf (CCASG), the Council was established on 25 May 1981 on signature of the Charter by Bahrain, Kuwait, Oman, Qatar, Saudi Arabia and the United Arab Emirates.

Aims. To assure security and stability of the region through economic and political co-operation; promote, expand and enhance economic ties on solid foundations, in the best interests of the people; co-ordinate and unify economic, financial and monetary policies, as well as commercial and industrial legislation and customs regulations; achieve self-sufficiency in basic foodstuffs.

Organization. The Supreme Council formed by the heads of member states is the highest authority. Its presidency rotates, based on the alphabetical order of the names of the member states. It holds one regular annual session in addition to a mid-year consultation session. Attached to the Supreme Council are the Commission for the Settlement of Disputes and the Consultative Commission. The Ministerial Council is formed of the Foreign Ministers of the member states or other delegated ministers and meets quarterly. The Secretariat consists of the following sectors: Political Affairs, Military Affairs, Legal Affairs, Human and Environment Affairs, Information Centre, Media Department, Gulf Standardization Organization (GSO), GCC Patent Office, Secretary-General's Office, GCC Delegation in Brussels, Technical Telecommunications Bureau in Bahrain. In Jan. 2003 it launched a customs union, introducing a 5\% duty on foreign imports across the trade bloc.

Finance. The annual budget of the GCC Secretariat is shared equally by the six member states.

Headquarters: PO Box 7153, Riyadh-11462, Saudi Arabia.

Website: http://www.GCC-SG.org

Secretary-General: Abdul Latif bin Rashid al-Zayani (Bahrain).

Publications. Attaawun (quarterly, in Arabic); GCC Economic Bulletin (annual); Statistical Bulletin (annual); Legal Bulletin (quarterly, in Arabic).

\section{Further Reading}

Twinam, J. W., The Gulf, Co-operation and the Council: an American Perspective. 1992

\section{League of Arab States}

Origin. The League of Arab States (often referred to as the Arab League) is a voluntary association of sovereign Arab states, established by a Pact signed in Cairo on 22 March 1945 by the representatives of Egypt, Iraq, Saudi Arabia, Syria, Lebanon, Jordan and Yemen. It seeks to promote closer ties among member states and to co-ordinate their economic, cultural and security policies with a view to developing collective co-operation, protecting national security and maintaining the independence and sovereignty of member states, in order to enhance the potential for joint Arab action across all fields.

Members. Algeria, Bahrain, Comoros, Djibouti, Egypt, Iraq, Jordan, Kuwait, Lebanon, Libya, Mauritania, Morocco, Oman, Palestine, Qatar, Saudi Arabia, Somalia, Sudan, Syria*, Tunisia, United Arab Emirates and Republic of Yemen. Observers. Brazil, Eritrea, India and Venezuela. ${ }^{\star}$ Membership suspended since Nov. 2011 after calls for the government to end violence against civilian protesters by a set date were ignored.

Joint Action. In the political field, the League is entrusted with defending the supreme interests and national causes of the Arab world through the implementation of joint action plans at regional and international levels. It examines any disputes that may arise between member states with a view to finding a peaceful resolution. The Joint Defence and Economic Cooperation Treaty signed in 1950 provided for the establishment of a Joint Defence Council as well as an Economic Council (renamed the Economic and Social Council in 1977). Economic, social and cultural activities constitute principal and vital elements of the joint action initiative.

Against the backdrop of the 2011 Arab Spring, the League backed a UN resolution authorizing action in Libya against Col. Gaddafi's air defences and suspended Syria for its government's oppression of the opposition movement. Also in 2011 the League supported a Palestinian bid for UN recognition.

Arab Common Market. An Arab Common Market came into operation on 1 Jan. 1965. Initial plans to abolish customs duties on agricultural products, natural resources and industrial products by 